\title{
The politics of contraception: policies lost and regained
}

\author{
Lindsay Edouard
}

\section{Summary}

Demography, health, human rights and morality have been important perspectives in the formulation of policies for the provision of contraceptive services. By addressing unmet need, implementation of the right to contraception leads to decreases in fertility and population growth, thereby promoting attainment of the Millennium Development Goals and poverty reduction in the context of international development. With demographic considerations having received short shrift for a long time, it is most appropriate that the issue of population growth is returning to the fore.

\section{Paradox}

Twenty-five years ago, management issues were at the forefront of health services and family planning was not exempt, special attention being paid to the efficient utilisation of resources. Kurji explored the feasibility of using routinely collected data for comparing the performance of clinics ${ }^{1}$ whilst Black demonstrated the cost-effectiveness of day-surgery female sterilisation in a family planning clinic as an alternative to overnight stay in a hospital setting. ${ }^{2}$

The long-term viability of some family planning services was threatened because some district health authorities had attempted to save money by closing clinics. The resulting shift of the workload to general practitioners would actually be more expensive, but would be charged to a different budget. ${ }^{3,4}$ Family planning clinics had numerous advantages with their convenient hours, accessibility for certain groups of hard-to-reach individuals with the greatest need and with a specialist service providing a wide range of contraceptive methods. Training schedules were being discussed for the proposed specialty of medical gynaecology, which would strengthen the family planning clinics. 5

In a detailed analysis of the fight for family planning in Britain, which "has been a long one and is by no means over", Leathard pointed out the paradox whereby the government had lately been "ignoring demographic input as distinct from outcome" when rationalising expenditures between individuals and the state. ${ }^{4}$

\section{Premise}

Demographic perspectives had long been prominent in the provision of family planning services in Britain. ${ }^{4}$ The independent pioneering efforts of Marie Stopes and the Malthusian League that led to the opening of birth control clinics in London in 1921 were initially opposed on demographic grounds that were linked to social class, gender, religion, medical profession and morality. With the "erosion of lingering Victorian taboos", "support of socially respected women" and "contributions of eminent medical men", there was increasing support for contraception by the end of the 1920 s, when government

\section{J Fam Plann Reprod Health Care 2009; 35(4): 257-259}

\section{Algiers, Algeria}

Lindsay Edouard, FRCOG, FFSRH, Member of the Editorial Advisory Board

Correspondence to: Professor Lindsay Edouard.

E-mail: soranae@gmail.com became favourable to the provision of contraceptive services to married women, albeit on limited medical grounds.

The National Birth Control Council was formed in 1930 with the aim of "a crusade against maternal ill-health and poverty caused by excessive child-bearing". 4 With fears of depopulation in the late 1930s, the term 'birth control' fell into disrepute and the agency changed its name to the Family Planning Association in 1939. During the Second World War, demographic fears increased to the extent that family planning was not addressed at all in the National Health Service bill of 1946. However, landmarks for the acceptance of contraception occurred with bold statements by the Minister of Health in 1955 and by Anglican bishops during the Lambeth Conference in 1958.

When hormonal contraceptive pills became available around 1960, interest in the provision of contraception services extended beyond a few pioneers to encompass the medical establishment, but there was opposition from various groups. In 1967, contraceptive services became available to all women, not only to those who were married. Increasing concerns in the $1970 \mathrm{~s}$ about overpopulation, illegitimacy and abortion led to advocacy by the Doctors and Overpopulation Group as well as the Birth Control Campaign: their success led to free government-provided family planning services in 1974. Irrespective of the rationale for contraceptive provision, the health benefits of family planning were well recognised.

\section{Peril}

At a symposium on "Politics of Contraception" held in London in November 1983, there was an attack on "the bigoted and narrow-minded who were unaware or uncaring of problems outside their own experience". 6 It was held that advocacy for family planning should be accompanied by provision of the best possible service despite any opposition.

Dr Elphis Christopher "gave a rapid fire account of the battle" that she faced over the free use of Depo-Provera ${ }^{\circledR}$ leading to her "hurt and bewilderment at being labelled anti-feminist and racist". 6 This unfortunate situation occurred despite the full support of the Clinical and Scientific Advisory Committee of the National Association of Family Planning Doctors for the licence granted for the long-term use of Depo-Provera for contraception in women for whom other methods were unsuitable. ${ }^{7}$

\section{Prospects}

The poor progress in the global effort to control population growth was deplored although there was some hope from recent successes. ${ }^{6}$ Senator Mary Robinson, then lecturer at Trinity College Dublin, was finally achieving some success in "her long drawn-out courageous campaign" for ensuring access to modern methods of contraception in the Republic of Ireland, particularly with the recognition by the Church that "legislation was for the legislators". 8 It was not until 1983 that intrauterine devices became available there and access to modern contraceptives continued to be "controlled in a very convoluted manner".

A survey of district medical officers in England and Wales by the Department of Health and Social Security merely led to the suggestion of some mild form of collaboration between their family planning services and hospital obstetrics and gynaecology departments without 
any serious attempt at integration as was the case for child health. ${ }^{9}$ In contrast, experience in developing countries had shown the value, especially for maternal and child health, of integration of family planning into a national health service. 10

Through discussion groups in Manchester, Brenda Spencer concluded that sex education for teenage males should be modified by getting them to appreciate their responsibilities. ${ }^{11}$ Gender issues had become evident in different ways in developing countries. Besides the lack of nurseries, caring for young children became more difficult for middle-class women as the availability of domestic help was decreasing due to increasing school enrolment and employment opportunities for poor girls. Conversely, the involvement of husbands in decision-making for contraceptive practice was not optimal as women feared that their spouses would suspect promiscuity and a subsequent "overlay of secrecy and guilt". ${ }^{10}$

\section{Privileges}

The language of rights was quickly infiltrating the vocabulary of family planning: for contraception provision in Britain, "the battle was far from over" as it was felt that the right to the number of children and the spacing of pregnancies must be accompanied by information and services that were needed to support the decision. ${ }^{6}$ The World Population Plan of Action, from the World Population Conference held in 1974, had stated in Article 14(f) that "all couples and individuals have the basic right to decide freely and responsibly the number and spacing of their children". The concept of rights was applied and exemplified both by a survey conducted by the Women's Reproductive Rights Campaign in London ${ }^{12}$ and the report on family planning as a basic human right from the International Planned Parenthood Federation. ${ }^{13}$ Furthermore, rights issues were highlighted in the biography of Dr Helena Wright, a pioneer of contraception, whose "life was dedicated to human happiness based on achieving normal sex lives for all her patients and the avoidance of unplanned and unwanted pregnancies". ${ }^{14}$

In a masterly global analysis, ${ }^{15}$ Fred Sai noted that "the negative politics of contraception find most fertile ground" in the poorer and less-developed countries, the fundamental issues being "whether people should have the freedom to separate sexual enjoyment from procreation" and the role of "imposed morality" to limit the availability of contraception, with allusions to "corrupting of morals and a looseness in sexual behaviour". He reminded readers that Gandhi referred to abuse of the creative function by the middle class, approval of sexual perversion by important personalities and the "havoc secret vice has played among schoolboys and schoolgirls", besides a view that "the introduction of contraceptives under the name of science and the imprimatur of known leaders of society has intensified the complication". 15 Opposition to family planning sometimes resulted from cultural and religious concerns: some societies, believing in reincarnation, perceived obstacles to the return of a popular deceased elder. Besides, opposition to family planning could be due to a numbers game to ensure political power, whether as applied differentially to ethnic groups within a country or between countries at the regional or global level, with confrontations on trade imbalances, conservation of natural resources and other concerns regarding regional differentials in per capita consumption of non-renewable resources. The media seemed to be more interested in the adverse effects of contraceptive products as opposed to the right of access to family planning services.

Sai went on to state that with opposition to multinational companies, the politics of contraception extended to the licensing of contraceptive products. Unfortunate negative rulings by regulatory authorities in Britain and the USA had led to injectable contraceptives being considered as poison with reports "from some of the African press that DMPA turned women into men, that it made them give birth to animals". With the need for a riskbenefit ratio that is more appropriate to less-developed countries, the establishment of their own regulatory authority was suggested whilst anticipating, correctly, that there would be no action during the following two decades. Sai's view was that the overall philosophy was "the right to private and safe contraception" with "insistence on voluntary informed choice" whilst "society should have no right to withhold contraceptives for demographic or other ends". 15

\section{Platforms}

In a review of health-related population issues in October 1985, the World Health Organization Regional Office for Africa stated that "the repercussions of an accelerated demographic growth rate are holding up implementation of the main national, health and social development objectives". It was noted that population policies emphasised mortality, health and well-being but that family planning was still facing strong opposition and that the "use of fashionable Western slogans such as "woman controls her body', 'equality of the sexes' and 'woman's liberation' go against socially acceptable norms and values in most African countries."16

Agreed in Bucharest in 1974 and in evidence at the International Conference on Population in Mexico City in 1984, the rights discourse gained much more prominence during the following decade. The path towards the primordial status of individual rights was charted during preparations for the International Conference on Population and Development held in Cairo in 1994, paragraph 1.11 of its Programme of Action mentioning "the crucial contribution that early stabilization of the world population would make towards the achievement of sustainable development". Individual rights were strongly supported at the Fourth World Conference on Women held in Beijing in 1995, paragraph 96 of its Platform for Action stating that "the human rights of women include their right to have control over and decide freely and responsibly on matters related to their sexuality".

Whereas numbers are central to family planning, the availability of contraceptive choices ${ }^{17}$ as part of a rightsbased approach would address unmet need and lead to fertility decline and a decrease in world population. ${ }^{18}$ Whilst influential bodies should avoid meddling in national sovereignty issues, there was a need "for people to be constructive and conciliatory" with common recognition of the crucial role of gender and education. ${ }^{19}$ Circumstances were thereby conducive for an evidence-based approach for support of population policies that would respect the rights of individuals.

For a life-cycle approach 'from womb to tomb' that encompassed birth and aging, it was stated that international reproductive health should become closer to population issues, but the latter were often seen as controversial, sometimes rhetorical and sadly political. ${ }^{20,21}$ With population control having been largely regarded as an outmoded 1970s concept, a carefully balanced view and multipronged strategies 22 are required to achieve acceptable changes in policy. Conscientious approaches, that transcend cultures, are often needed in contentious controversies that cannot be solved by consensus statements. 


\section{Population growth factor}

In January 2007, an All Party Parliamentary Group of the House of Commons made unequivocal statements on the detrimental effects of high population growth, especially on the Millennium Development Goals. Its recommendations focused on meeting unmet needs and implementing a rightsbased approach, thereby decreasing population growth. ${ }^{23}$

There is now an urgent need to formulate policies and enact legislation that will promote individual rights, knowing that they would lead to population stabilisation, thereby also ending the major demographic divide that has bothered liberals for more than two decades. The search for policies that would promote fertility decline has confirmed the continuing hampering roles of poor education and high infant mortality. ${ }^{24}$ For example, strong support in Iran ${ }^{25}$ for family planning services, based on a demographic rationale, led to great success as reflected in the total fertility rate, which is now below replacement level, with 1.83 children per woman.

\section{Priorities}

Family planning is the central component of reproductive health: it is a pillar for maternal and child health, besides having a crucial link with the control of sexually transmitted infections including HIV. When maternal mortality is high and contraceptive prevalence is not optimal, it is difficult to justify the prioritisation of certain other components of reproductive health care that need sophisticated tests. ${ }^{26}$ Decision-making should draw upon local epidemiology in setting priorities, and interdisciplinary discussions are valuable in depoliticising sensitive issues in order to get agreements.

Climate change is being increasingly linked to certain health issues and the value of lower population growth has been well documented. 27,28 With the special attention paid to climate change by the G8 at its meeting in L'Aquila, Italy in July 2009, it will be most interesting to monitor policy developments and the ensuing allocation of resources. With its rationale of health, human rights and demographics, contraception should feature even more prominently in efforts and resource allocation for international development. ${ }^{29}$

In rescinding the Bush administration's global gag rule on 23 January 2009, President Obama stated that he wanted to end the "stale and fruitless debate" about the value of family planning in global health. ${ }^{30}$ Policymakers and service providers should reflect on the wider implications by thinking much beyond the low-hanging fruits of conventional clinical encounters, by focusing on comprehensive outreach services and rights with their implications for demography. Whilst Thomas Malthus addressed population growth in the context of poor relief when contraceptive services had yet to be recognised, providers of family planning services should be proud of their crucial role in current efforts to achieve the Millennium Development Goals and their associated focus on poverty reduction in international development.

Statements on funding and competing interests

Funding None identified.

Competing interests None identified.
References

1 Kurji KH. Measuring the performance of family planning clinics: an index of efficiency. Br J Fam Plann 1984; 10: 75-77.

2 Black TRL, Eddy J, Lavely K. Female sterilisation in a nonhospital setting - a report from Marie Stopes House on 3,637 cases. Br J Fam Plann 1984; 9: 113-117.

3 Cardy G. Why we still need family planning clinics. Br J Fam Plann 1984; 10: 22-23.

4 Leathard A. The fight for family planning. Br J Fam Plann 1984; 10: 19-22.

5 Lincoln R. Reports - NAFPD Affiliated Groups Meeting, January 1984. Br J Fam Plann 1984; 10: 29-30.

6 Wakley G. Politics of contraception. Br J Fam Plann 1984; 10: 29.

7 Anonymous. From the Clinical and Scientific Advisory Committee. Br J Fam Plann 1984; 10: 38.

8 Hughes R. Reports - National Association of Family Planning Doctors. Br J Fam Plann 1984; 10: 62-63.

9 Anonymous. DHSS survey of community health services. $\mathrm{Br} \mathrm{J}$ Fam Plann 1984; 10: 23.

10 Oyediran MA. Family planning in Nigeria. Br J Fam Plann 1984; 9: $110-112$

11 Spencer B. Young men: their attitudes towards sexuality and birth control. Br J Fam Plann 1984; 10: 13-19.

12 Main A. Reports. Br J Fam Plann 1984; 10: 61-62.

13 Anonymous. The human right to family planning. $\mathrm{Br} J$ Fam Plann 1984; 10: 61.

14 Infield J. Freedom to choose. Br J Fam Plann 1984; 10: 59

15 Sai FT. Contraceptives and their politics. Br J Fam Plann 1984; 10: $38-44$.

16 World Health Organization. Health-related population issues. Report of a Study Group, Brazzaville, 7-9 October 1985. Document AFR/MCH/82. Brazzaville, Republic of the Congo: World Health Organization Regional Office for Africa, 1985: $2-3,5,11,48,51,57$.

17 Djerassi C. The Politics of Contraception. New York, NY: W W Norton, 1979.

18 Potts M. The population policy pendulum. BMJ 1999; 319: 933-934.

19 Safire W. Vatican vs VP: papal population politics. New York Times, 5 September 1994; section 1, page 17.

20 King M, Elliott $C$. To the point of farce: a Martian view of the Hardinian taboo - the silence that surrounds population control. BMJ 1997; 315: 1441-1443.

21 Editorial. The World Bank in turmoil. Lancet 2007; 369: 1492.

22 Cleland J, Sinding S. What would Malthus say about AIDS in Africa? Lancet 2005; 366: 1899-1901.

23 House of Commons. Return of the population growth factor its impact upon the Millennium Development Goals. Report of hearings by the All Party Parliamentary Group on Population, Development and Reproductive Health. London, UK: House of Commons, 2007: 56-63.

24 United Nations. Prospects for fertility decline in high fertility countries. Population Bulletin of the United Nations (Special Issue 46/47). 2002. Department of Economic and Social Affairs, Population Division. Document ST/ESA/SER.N/46-47. New York, NY: United Nations, 2007; ix, 3-17, 43, 51.

25 Hoodfar $\mathrm{H}$, Assadpour $\mathrm{S}$. The politics of population policy in the Islamic Republic of Iran. Stud Fam Plann 2000; 31: 19-34.

26 Gotzsche PC, Hartling OJ, Nielsen M, Brodersen J, Jorgensen KJ. Breast screening: the facts - or maybe not. BMJ 2009; 338: 446-448.

27 Coombes $R$. Experts call for a global fund for family planning. BMJ 2009; 338: 792-793.

28 Costello A, Abbas M, Allen A, Ball S, Bell S, Bellamy R, et al. Managing the health effects of climate change. Lancet 2009; 373: 1693-1733.

29 Banatvala N, Bland S, Donaldson L. Working with WHO: the UK's institutional strategy. Lancet 2009; 373: 1827-1829.

30 Office of the Press Secretary. Statement of President Barack Obama on rescinding the Mexico City policy. 23 January 2009. Washington, DC: The White House, 2009.

\section{Visit the Faculty Website at www.fsrh.org}

